\title{
HEALTH CENTERS PREPAREDNESS IN FACING THE COVID-19 PANDEMIC IN KARANGANYAR, CENTRAL JAVA, INDONESIA
}

\author{
Fajar Novianto',2), Saryanto',2), Tofan Aries Mana'), Nur Rahmawati \\ Wijaya'), Ahmad Saikhu'), Harimat Hendarwan3) $^{2}$ \\ 1)Masters Program in Public Health, Universitas Sebelas Maret \\ 2) Center for Research and Development of Medicinal Plants \\ and Traditional Medicines, Tawangmangu, Indonesia \\ ${ }^{3)}$ Center for Research and Development of Health Resources \\ and Services, Jakarta, Indonesia
}

\begin{abstract}
Background: COVID-19 is a highly contagious respiratory disease. Preparedness of health facilities to prevent the spread of COVID-19 is an immediate priority to safeguard patients and healthcare workers and to reduce the spread of the pandemic. However, the preparedness of health centers in Karanganyar, Central Java is unknown.

Subjects and Method: A cross sectional study was conducted at 21 community health centers in Karanganyar, Central Java, Indonesia. The research problem was health centers preparedness in facing the COVID-19 pandemic. The data were collected twice in April and September 2020 by questionnaire.

Results: At the beginning of the COVID-19 pandemic, in April 2020, many health centers in Karanganyar were not ready to face the COVID-19 pandemic. After the second measurement in September 2020, there was an increase in the readiness of the health centers in terms of health workers and facilities availability.

Conclusion: Public Health Centers in Karanganyar are increasing readiness to face the COVID-19 pandemic by providing more facilities and the number of health workers in the COVID-19 treatment unit.
\end{abstract}

Keywords: COVID-19, community health center, pandemic preparedness

\section{Correspondence:}

Fajar Novianto. Center for Research and Development of Medicinal Plants and Traditional Medicines, Tawangmangu, Indonesia. Jl. Raya Lawu 11, Tawangmangu, Karanganyar, Central Java. Email: dr.fajarnovianto@gmail.com. Mobile: 081330700298. 